\title{
Anthropometric assessment of women worker in selected hosiery units of Ludhiana City
}

Kanchan Shilla, Pushpinder Sandhu and Sharan Bir Kaur Bal

Received: 03.12.2017; Revised: 04.04.2018; Accepted: 22.04.2018

See end of the paper for authors' affiliations Kanchan Shilla

Department of Family Resource Management, College of Home Science, Punjab Agricultural University, Ludhiana (Punjab) India
ABSTRACT : The present study was conducted to assess the anthropometry of women worker in hosiery units of Ludhiana City using survey method on a sample of 120 women workers. Data pertaining to anthropometric measurements of women worker in hosiery units was collected by using duly pretested and finalized interview schedule. Anthropometer was used to record anthropometric data of workers. It was observed that mean standing height, popliteal height, elbow height, horizontal side way arm reach, frontal horizontal arm reach, sitting height, shoulder height, eye height and vertical arm reach of the respondents were $157.73 \pm 6.27 \mathrm{~cm}$; $53.94 \pm 3.55 \mathrm{~cm} 100.34 \pm 7.04 \mathrm{~cm} ; 189.08 \pm 8.89 \mathrm{~cm} ; 39.83 \pm 2.67 \mathrm{~cm} ; 86.45 \pm 5.75 \mathrm{~cm} ; 65.53 \pm 8.13 \mathrm{~cm}$; $73.67 \pm 11.69 \mathrm{~cm}$ and $197.60 \pm 8.05 \mathrm{~cm}$, respectively.

KEY WORDS: Women worker, Anthropometry, Hosiery units

- HOW TO CITE THIS PAPER : Shilla, Kanchan, Sandhu, Pushpinder and Bal, Sharan Bir Kaur (2018). Anthropometric assessment of women worker in selected hosiery units of Ludhiana City. Asian J. Home Sci., 13 (1) : 202-206, DOI: 10.15740/HAS/AJHS/13.1/202-206.Copyright@ 2018: Hind Agri-Horticultural Society. 